\title{
Tax aspects of foreign income of Russian seafarers
}

\author{
Elena Lavrenteva $^{1}$ and Aleksandra Brovkina ${ }^{1, *}$ \\ ${ }^{1}$ Admiral Makarov State University of Maritime and Inland Shipping, 5/7, Dvinskayastr, Saint- \\ Petersburg, Russia, 198035
}

\begin{abstract}
The paper discusses the features of taxation of foreign income of individuals. The main object of the study is the income of seafarers working on ships under a foreign flag, the peculiarities of the calculation and taxation of their wages. The statistical data on the level of wages and the structure of expenses of the families of seafarers are given. The methodological approaches to assessing the indirect contribution of seafarers working for foreign shipowners to the revenue side of the state budget through the purchase of goods, works and services on the territory of the Russian Federation have been substantiated. The proposed algorithm includes four stages. The first stage is the determination of the number of seafarers working on foreign ships. The second stage is the determination of the salaries of seafarers working on ships under a foreign flag. The third stage is the substantiation of the expenses of seafarers on the territory of the Russian Federation. The fourth stage is an assessment of the contribution of seafarers to budget revenues through indirect tax revenues from the goods, works and services they purchase. The paper highlights the main global trends in the issues of state regulation of foreign income of seafarers.
\end{abstract}

\section{Introduction}

In the scientific literature, much attention is paid to the issues of income taxation, including in shipping, both in foreign sources and in Russian publications. Foreign authors more often consider the labor income of seafarers in the context of employment [1,2] or as a factor in the competitiveness of companies choosing international crews [3,4,5]. Works on the income of labor migrants $[6,7]$ and taxation of income earned outside the country of residence are of interest $[8,9,10,11]$. Many aspects of income taxation are methodologically substantiated and have been practically implemented in legislative and regulatory documents. The list of individual incomes of citizens, subject and not subject to taxation, was theoretically and methodically determined.Approaches to the recognition of persons as tax residents in Russia were formed, tax rates for various types of income of citizens were established, etc. At the same time, the discussion about the advisability of a flat, progressive or regressive scale of taxation continues.However, there are issues that have not been considered and require in-depth study, both from the point of view of taxation and

\footnotetext{
*Corresponding author: brovkinaav@mail.ru
} 
socio-economic importance for the state economy. These are foreign incomes of Russian citizens, in particular, seafarers working abroad, i.e. on ships of foreign shipowners. In this case, as a rule, the ship's crew concludes contracts for work through intermediaries crewing companies, and wages are received directly from foreign ship owners. Thus, such employees do not have employerson the territory of Russia; personal income tax and insurance contributions to extra-budgetary funds are not paid. At the same time, they are citizens of the Russian Federation, having all the rights. At first glance, there is a social contradiction, but it should be borne in mind that almost all the money earned by seafarers is imported and spent in Russia, indirectly replenishing the budgets of all levels. This situation is of a systemic nature, but the example of seafarers is most revealing.

\section{Materials and methods}

To study the problem posed, it is necessary to determine the methods and information base of the main constituent aspects: income taxation, wages and the structure of seafarers' expenses, the indirect contribution of seafarers to the state budget.

The first aspect is the procedure for taxing income. In accordance with the general Russian legislative procedure, income received by Russians abroad is subject to taxation for tax residents, who are individuals who actually stay in the Russian Federation for at least 183 calendar days within 12 consecutive months. This period is not interrupted by shortterm (less than six months) travel abroad for treatment, education or work (provision of services) at offshore hydrocarbon deposits [Tax Code of the Russian Federation, Art. 207, Art. 209].

According to the established practice, foreign shipowners conclude contracts with seafarers for four months with the condition of reduction or extension by one month, depending on the operational need and the possibility of changing the ship's crew. Then the seafarer is on the shore for four months, therefore, according to the standard employment scheme, he works on the ship for 8 months (about 240 days) for 12 months and is not a tax resident in Russia. The majority of foreign shipping companies do not make any payments to the seafarer during the period when he is out of the ship after the end of the contract.

The second aspect is wages, i.e. the main source of individual income for seafarers. At the international level, the Maritime Labor Convention, 2006 (hereinafter the Convention) (The 2006 Maritime Labor Convention, concluded in Geneva on February 23, 2006 (Collected Legislation of the Russian Federation, 2013, No. 34, art. 4429); Federal Law of June 5, 2012 N 56-FZ "On Ratification of the 2006 Maritime Labor Convention" (Collected Legislation of the Russian Federation, 2012, N 24, Art. 3073)), lays down the wage requirements for seafarers. This Convention has been ratified by 97 states with $91 \%$ of the world's gross tonnage (https://www.ilo.org/global/standards/maritime-labourconvention/lang--en/index.htm, date of access: 07.01.2021), namely:

- in accordance with the collective and labor agreement, wages must be paid on a regular basis at least once a month;

- for the amounts accrued and paid, seafarers are provided with a report including wages, additional payments and exchange rates used in cases where payments are made in foreign currency or at rates that differ from those agreed;

- it is necessary to create conditions so that seafarers can transfer, by bank transfer or in another similar way, their earnings or a part of them to their families, dependents, or trusted persons. At the same time, the fees for such services should be reasonable in terms of the amount and exchange rates.

When making wages, it is recommended to use the following definitions: 
- base salary or wages means payment, whatever its structure, for work during normal working hours; it does not include overtime payments, bonuses, benefits, paid leave or any other additional remuneration;

- lump-sum wages means wages that include basic wages and other related payments; in addition, it may include compensation for all overtime work performed and all other payrelated benefits, or it may include only certain types of benefits with a partial summation.

It is important to emphasize that there is no minimum wage for seafarers in the mandatory provisions of this Convention. This issue is being considered at the meetings of the Joint Maritime Commission created and operating within the framework of the International Labor Organization (ILO). There, representatives of shipowners and seafarers decide on the minimum wage for a qualified sailor (class I sailor), which has a recommendatory character, but shipowners take it into account when developing corporate salary systems for seafarers. Figure 1 shows the dynamics of changes in the minimum wage rate for a qualified sailor.

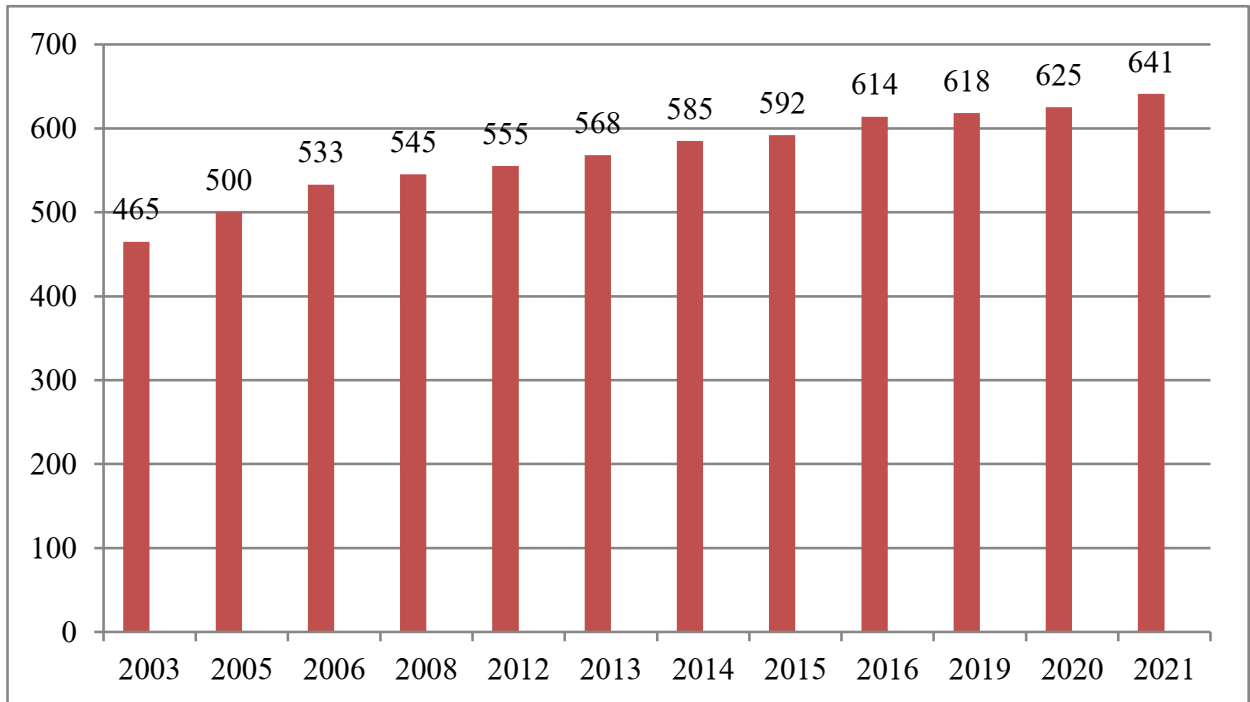

Fig. 1. Minimum rate for a class I sailor in accordance with the decisions of the ILO Joint Maritime Commission, USD.

The salary of seafarers depends on the type, carrying capacity of the ship and the policy of the shipping company in the field of personnel management.In practice, it has a very significant differentiation by position and by ship. For example, the salary of a ship's captain ranges from USD 5,000 to USD 25,000 per month, depending on the purpose and capacity of the ship. The dynamics of the remuneration of the second mechanic on various ships is shown in Figure 2 (https://maritime-zone.com/news/view/zarplata-morjakovrejting-sajta-maritime-zone-com, access date - 02.07.2020). 


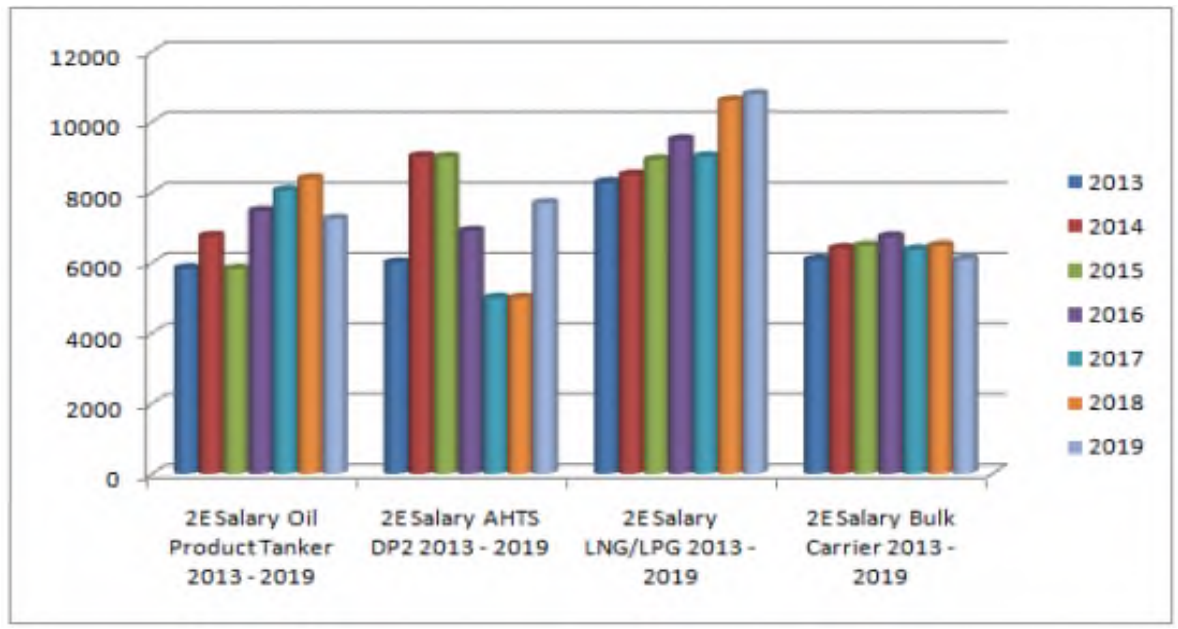

Fig. 2. Remuneration of the second mechanic,USD.

The highest salaries in the maritime sector, according to the Maritime-zone portal, are shown in Figure $3^{3}$. It is important to emphasize that over the past 6 years, the salaries of merchant marine seafarers have not changed significantly, while the salaries of offshore specialists first increased and then fell sharply along with oil prices. Nevertheless, salaries in the oil and gas segment are still high and remain a worthy goal for many professionals (https://maritime-zone.com/news/view/zarplata-morjakov-rejting-sajta-maritime-zone-com, access date $-02.07 .2020)$.

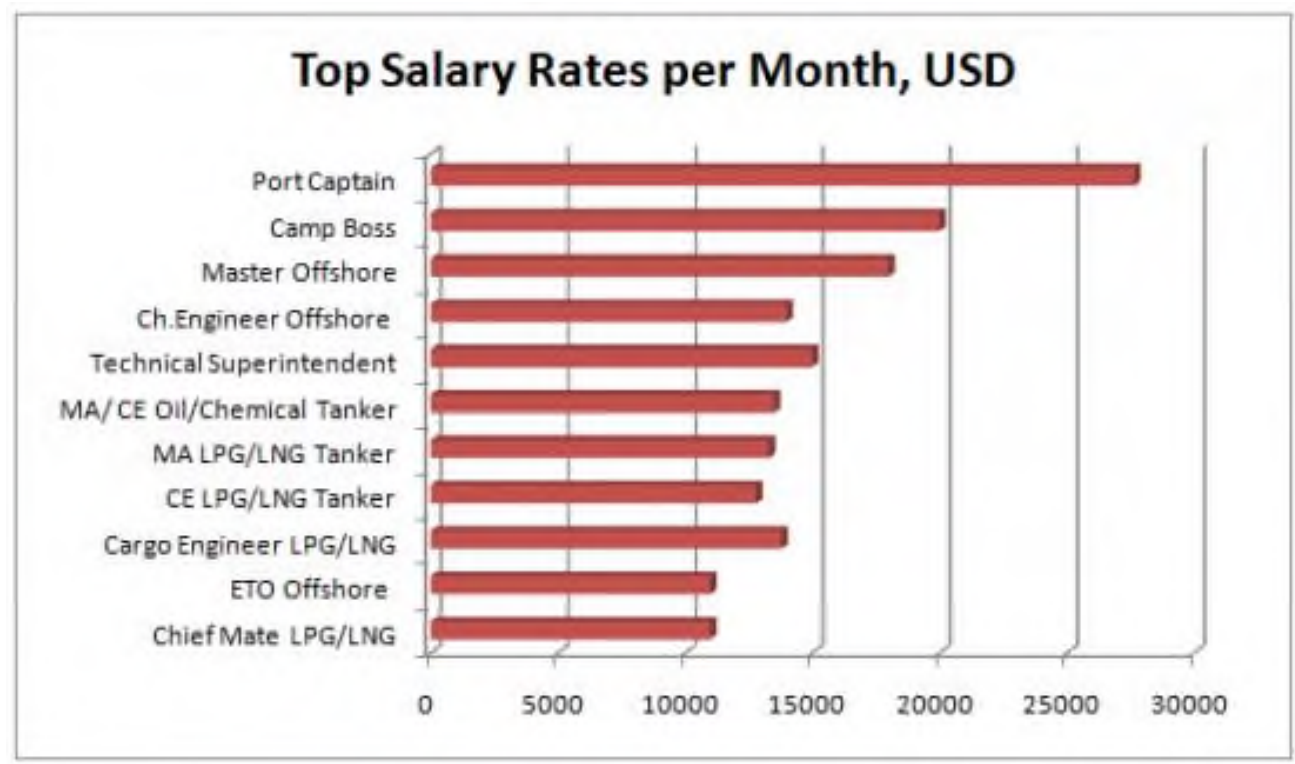

Fig. 3. Highest wages for seafarers per month, USD.

The above data on high wages are not widespread. On average, in 2020, foreign owners of dry cargo vessels (container ships, refrigerators) offered contracts with the salary presented in the table1 (according to the information portal "Who? Where? How much?"https://ktogdeskolko.com/skolko-zarabatyvayut-moryaki access date: 10.01.21). 
Table 1. Salary of seafarers depending on the position and type of vessel.

\begin{tabular}{|l|c|c|}
\hline \multirow{2}{*}{ Position } & \multicolumn{2}{c|}{ Type of vessel } \\
\cline { 2 - 3 } & Dry cargo ship & Tanker/gas carrier \\
\hline Captain & 8000 & 10000 \\
\hline Chief mate & 5500 & 7000 \\
\hline Second mate & 3500 & 4500 \\
\hline Third mate & 3000 & 4000 \\
\hline Chief mechanic & 8000 & 10000 \\
\hline Second mechanic & 5500 & 7500 \\
\hline Third mechanic & 3000 & 4000 \\
\hline Electrical officer (electrician) & 5000 & 5500 \\
\hline Boatswain & 1500 & 2000 \\
\hline Sailor & 1000 & 1200 \\
\hline Motor man & 1000 & 1500 \\
\hline Cook & 1300 & 1800 \\
\hline
\end{tabular}

The third aspect of the problem under consideration is the structure of seafarers' expenses. To this end, it is advisable to analyze statistical data on the distribution of household resources, which is shown in Table 2 (https://www.gks.ru/folder/13397 (access date: 08.01.2021)). According to statistical methodology, a household is several persons living in the same dwelling or part of it, both related and not related by kinship relations, jointly providing themselves with everything necessary for life, fully or partially combining and spending their funds. A household can consist of one person living independently (https://rosstat.gov.ru/free_doc/new_site/population/urov/murov61.htm access date: 08.01.2021).

Table 2. The structure of household consumption expenditures, $\%$.

\begin{tabular}{|c|c|c|c|c|c|}
\hline Indicators & $\mathbf{2 0 1 5}$ & $\mathbf{2 0 1 6}$ & $\mathbf{2 0 1 7}$ & $\mathbf{2 0 1 8}$ & $\mathbf{2 0 1 9}$ \\
\hline Consumer expenses - total & $\mathbf{1 0 0}$ & $\mathbf{1 0 0}$ & $\mathbf{1 0 0}$ & $\mathbf{1 0 0}$ & $\mathbf{1 0 0}$ \\
\hline including for: & & & & & \\
\hline food and soft drinks & 32.1 & 32.3 & 31.2 & 30.7 & 29.8 \\
\hline alcoholic beverages, tobacco products & 3.0 & 3.1 & 3.0 & 3.0 & 3.0 \\
\hline $\begin{array}{c}\text { clothes and shoes } \\
\text { housing services, water, electricity, gas } \\
\text { and other fuels }\end{array}$ & 9.2 & 9.2 & 8.8 & 8.0 & 8.2 \\
\hline $\begin{array}{c}\text { household items, appliances and home } \\
\text { care }\end{array}$ & 5.5 & 11.3 & 10.9 & 9.9 & 10.8 \\
\hline health care & 3.7 & 3.6 & 5.3 & 5.9 & 5.3 \\
\hline transport & 14.4 & 13.3 & 16.0 & 16.7 & 16.1 \\
\hline $\begin{array}{c}\text { mobile connection } \\
\text { organization of recreation and cultural } \\
\text { events }\end{array}$ & 3.3 & 3.3 & 3.1 & 3.2 & 3.1 \\
\hline education & 0.9 & 6.7 & 6.9 & 7.8 & 8.4 \\
\hline hotels, cafes and restaurants & 3.5 & 3.5 & 3.3 & 3.5 & 3.5 \\
\hline other goods and services & 6.9 & 7.1 & 6.9 & 7.0 & 7.1 \\
\hline
\end{tabular}

The structure of consumer expenditures shown in Table 2 must be adjusted for the prevailing consumption of various socio-economic categories of households, shown in Table $3^{6}$. 
Table 3. The structure of consumer expenditures by households of various socio-economic categories in $2019, \%$.

\begin{tabular}{|l|c|c|c|}
\hline Consumption costs & All households & $\begin{array}{c}\text { Households of 4 } \\
\text { people }\end{array}$ & $\begin{array}{c}\text { Households with 2 } \\
\text { children under 16 }\end{array}$ \\
\hline $\begin{array}{l}\text { Total, } \\
\text { Including }\end{array}$ & 100 & 100 & 100 \\
\hline food & 35.2 & 35.4 & 34.4 \\
\hline $\begin{array}{l}\text { including the cost of } \\
\text { in-kind food receipts }\end{array}$ & 3.2 & 3.6 & 3.5 \\
\hline Non-food products & 36.0 & 36.6 & 38.1 \\
\hline Alcoholic beverages & 1.6 & 1.4 & 25.8 \\
\hline Payment for services & 27.0 & 26.4 & 0.2 \\
\hline $\begin{array}{l}\text { The cost of services } \\
\text { provided by the } \\
\text { employer free of } \\
\text { charge or at reduced } \\
\text { prices }\end{array}$ & 0.2 & 0.2 & \\
\hline
\end{tabular}

The resulting aspect is the assessment of the indirect contribution of seafarers working for foreign shipowners to the revenue side of the state budget through the purchase of goods, works and services on the territory of the Russian Federation.

\section{Results}

To solve the problem, it is advisable to use the following substantiation algorithm:

Stage 1. Determination of the number of seafarers working on foreign ships.

Stage 2. Determination of the salaries of seafarers working on ships under a foreign flag.

Stage 3. Substantiation of seafarers' expenses on the territory of the Russian Federation.

Stage 4. Assessment of the contribution of seafarers to budget revenues through indirect tax revenues from the goods, works and services they purchase.

Stage 1. Determination of the number of seafarers working on ships of foreign shipowners.

The work of seafarers on ships of foreign shipowners is typical for the world sea transport. According to MaritimeZone, there are 1,647,500 seafarers in the world, of which 774,000 are command personnel and 873,500 are private. Currently, there is a shortage of commanders in the crewing market - about 16,500 - and a surplus of privates - about 119,000 people (https://seanews.ru/2020/02/27/ru-nacionalnost-morjaka-kak-faktorzarabotnoj-platy/ access date: 08.01.2021).

According to the International Chamber of Shipping, there are 5 main crewing countries that provide the main inflow of seafarers to ships: the Philippines (the world leader in providing the merchant marine with enlisted personnel); China (the largest supplier of commanders in the world, and the second largest country in terms of the number of privates); Indonesia; Russia; Ukraine. Filipinos account for the largest share of seafarers 400,000 out of 1.6 million of the world's seafarers (https:/www.nytimes.com/2019/11/30/world/asia/philippines-mariners-cargo-ships.html (access date: 15.09.2020)).Moreover, more than 260 thousand Filipino seafarers work on ships of foreign countries (https://crew-man.com/news/v-chem-sekret-populyarnostifilippinskih-moryakov.html(access date: 25.09 .2020$)$ ), but in recent years, more and more seafarers have been attracted from Vietnam, Myanmar and China. For Russian seafarers, this form of labor relations is also widely used. 
The Russian Federation has established a licensing system for the employment of Russian citizens outside Russia, which defines general requirements regarding the availability of appropriate premises for an applicant for this activity, as well as the qualifications of personnel. At the same time, only for companies for the overseas employment of seafarers, separate responsibilities have been established, among which are maintaining and keeping up to date the list of employed workers, providing access to the specified list of the licensing authority (Decree of the Government of the Russian Federation of 08.10.2012 N1022 "On approval of the regulation on licensing activities related to the provision of employment services for citizens of the Russian Federation outside the territory of the Russian Federation").

However, there is no accurate accounting and statistics of the number of seafarers employed by foreign shipowners. Industry experts note that over 100,000 Russian seafarers work for foreign shipowners (Rossiyskaya Gazeta - Federal Issue No.0(4295) https://rg.ru/2007/02/15/moryaki.html(access date 17.09.2020)). It is difficult to estimate their real number, since there are no effective methods to control their travel abroad to work. Crewing companies that provide intermediary services for the selection and registration of crew members are obliged to provide data on persons leaving for employment abroad. However, there is no well-functioning mechanism for monitoring the correctness of the submitted data. When hiring on a foreign ship, the document confirming employment is an employment contract (agreement) concluded directly with the ship owner. This document, according to international requirements (The 2006 Maritime Labor Convention, concluded in Geneva on February 23, 2006 (Collected Legislation of the Russian Federation, 2013, No. 34, art. 4429); Federal Law of June 5, 2012 N 56-FZ "On Ratification of the 2006 Maritime Labor Convention" (Collected Legislation of the Russian Federation, 2012, N 24, Art. 3073)), is kept by the shipowner and the seafarer, and there is no obligation to send it to the crewing company or port authorities.

Step 2. Determination of seafarers' wages.

In this study, for the calculation, the remuneration of the crew of a small sea vessel with a displacement of 6800 tons, a carrying capacity of 3500 tons, with a crew of 8 people is considered. The salary of the ship's crew is given in table 4 .

Table 4. Salaries of the ship's crew.

\begin{tabular}{|c|l|c|}
\hline No. & \multicolumn{1}{|c|}{ Position } & Salary, USD/month \\
\hline 1 & Ship captain & 10000 \\
\hline 2 & Chief mate & 9000 \\
\hline 3 & Second navigation assistant & 4000 \\
\hline 4 & Third navigation assistant & 2500 \\
\hline 5 & Chief mechanic & 9000 \\
\hline 6 & Sailor & 1800 \\
\hline 7 & Motor man & 1800 \\
\hline 8 & Cook (sailor) & 2200 \\
\hline & Salary fund for ship's crew & 40300 \\
\hline & Average salary & 5037.5 \\
\hline
\end{tabular}

For further calculations, we will conditionally accept the average salary of a seafarer in the amount of 5000 USD per month and, as mentioned above, the seafarer works on the ship for 8 months during a calendar year and does not receive salary in other periods of time. Thus, on average, according to aggregated calculations, a seafarer can receive 40,000 USD for a calendar year.

Stage 3. Substantiation of seafarers' expenses on the territory of the Russian Federation. 
To assess the expenses of a seafarer for the purchase of products, works and services in Russia, it is necessary to model such costs using the example of an average family of four: husband, wife (not working) and two children, ages 6 and 15 .

It is advisable to perform calculations in the context of the calendar year. Suppose that a sailor spends $10 \%$ of the earned money outside the Russian Federation, thus 36,000USD ( $90 \%$ of 40,000 USD) is annually imported into Russia.

Based on the statistical data given in Tables 2 and 3, the expenses for the conditions of the considered family of the seafarer were formed, which is shown in Table 5.

Table 5. Expenses of a seafarer's family based on established statistical proportions.

\begin{tabular}{|l|c|c|}
\hline \multicolumn{1}{|c|}{ Indicators } & Share, \% & $\begin{array}{c}\text { Expenses per year, } \\
\text { USD. }\end{array}$ \\
\hline $\begin{array}{l}\text { Consumer expenses - total, } \\
\text { including: }\end{array}$ & 100 & 36000 \\
\hline food and soft drinks & 29.8 & 10728 \\
\hline alcoholic beverages, tobacco products & 3 & 1080 \\
\hline clothes and shoes & 8.2 & 2952 \\
\hline housing services, water, electricity, gas and other fuels & 10.8 & 3888 \\
\hline household items, appliances and home care & 5.3 & 1908 \\
\hline health care & 3.8 & 1368 \\
\hline transport & 16.1 & 5796 \\
\hline mobile connection & 3.1 & 1116 \\
\hline organization of recreation and cultural events & 8.4 & 3024 \\
\hline education & 0.9 & 324 \\
\hline hotels, cafes and restaurants & 3.5 & 1260 \\
\hline other goods and services & 7.1 & 2556 \\
\hline
\end{tabular}

For greater reliability of the calculations, the authors conducted a survey on the structure of seafarers' expenses, the results of which are presented in Table 6.

Table 6. Structure of expenses of seafarers' families according to the results of the survey.

\begin{tabular}{|l|c|c|}
\hline \multicolumn{1}{|c|}{ Cost item } & Expenses per year, USD & Share, $\%$ \\
\cline { 1 - 1 } Total expenses. & 36000 & 100 \\
\cline { 1 - 1 } including: & 12020.4 & 33.39 \\
\hline food & 1411.2 & 3.92 \\
\hline communal payments & 496.8 & 1.38 \\
\hline mobile communications and internet & 2073.6 & 5.76 \\
\hline transportation costs & 2919.6 & 8.11 \\
\hline non-food products & 2487.6 & 6.91 \\
\hline children's clubs & 1494 & 4.15 \\
\hline education & 1825.2 & 5.07 \\
\hline entertainment and sports & 5803.2 & 16.12 \\
\hline mortgage & 3812.4 & 10.59 \\
\hline $\begin{array}{l}\text { savings for holidays on the territory of the } \\
\text { Russian Federation }\end{array}$ & 1659 & 4.61 \\
\hline unexpected expenses & &
\end{tabular}

Stage 4. Assessment of the contribution of seafarers to budget revenues through indirect tax revenues from the goods, works and services they purchase.

The given expenses of seafarers are, on the one hand, an incentive for the activity of the relevant business and the profitability of a certain type of activity, and on the other hand, they indirectly contribute to the receipt of tax revenues in the budget.

The current open statistical reporting does not allow us to accurately determine the tax receipts according to the presented details (Table 6). However, for an aggregated 
assessment, one can use the available statistical data on the taxes accrued and the sectoral turnover of sold products, works and services, which is shown in Table 7.

Table 7. Taxes accrued to the budgetary system of the Russian Federation (as of 01.01.2020).

\begin{tabular}{|l|c|c|c|}
\hline \multicolumn{1}{|c|}{ Type of economic activity } & $\begin{array}{c}\text { Accrued taxes, } \\
\text { RUB million* }\end{array}$ & $\begin{array}{c}\text { Turnover of } \\
\text { organizations by } \\
\text { type of economic } \\
\text { activity, RUB } \\
\text { million** }\end{array}$ & $\begin{array}{c}\text { Share of } \\
\text { accrued taxes } \\
\text { in the industry } \\
\text { turnover, \% }\end{array}$ \\
\hline $\begin{array}{l}\text { Provision of electricity, gas } \\
\text { and steam; air conditioning }\end{array}$ & 699352.245 & 9985300 & 7 \\
\hline Wholesale and retail trade & 2168012.552 & 78252000 & 3 \\
\hline Transport and storage & 845283.554 & 13476500 & 6 \\
\hline Hotel and catering activities & 140708.062 & 1372500 & 1 \\
\hline $\begin{array}{l}\text { Information and } \\
\text { communication activities }\end{array}$ & 712009.839 & 42281000 & 1 \\
\hline Education & 369905.605 & 61320000 & 4 \\
\hline $\begin{array}{l}\text { Activities in the field of health } \\
\text { and social services }\end{array}$ & 324542.962 & 29841100 & 4 \\
\hline $\begin{array}{l}\text { Activities in the field of } \\
\text { culture, sports, leisure and } \\
\text { entertainment }\end{array}$ & 123389.984 & 3110000 & 1 \\
\hline
\end{tabular}

Note: *https://www.nalog.ru/rn78/related_activities/statistics_and_analytics/forms/8708078/ (access date: 10.10.2020), ${ }^{* *}$ https://rosstat.gov.ru/bgd/regl/b20_11/Main.htm, item 15.3 (access date: 10.10.2020).Compiled by the authors according to the data of the Federal State Statistic Service "Russia in Figures 2020" and the Federal Tax Service of Russia "Report on the receipt of taxes, fees and insurance contributions to the budgetary system of the Russian Federation for the main types of economic activity. 1-NOM".

Based on the data in table 6 and table 7, a systematization and an aggregated assessment of the amounts of tax revenues, which the budget indirectly receives from the seafarer's consumption expenses, is carried out (Table 8).

Table 8. Taxes indirectly transferred to the budget from the consumption expenses of the seafarer.

\begin{tabular}{|c|c|c|c|}
\hline Cost item & $\begin{array}{c}\text { Seafarer's } \\
\text { expenses, USD }\end{array}$ & $\begin{array}{l}\text { Share of taxes } \\
\text { paid to the } \\
\text { budget, \% }\end{array}$ & $\begin{array}{l}\text { The amount of } \\
\text { taxes paid to the } \\
\text { budget, USD }\end{array}$ \\
\hline Food & 12020.4 & 3 & 360.61 \\
\hline Non-food products & 2919.6 & 3 & 87.59 \\
\hline Housing services & 1411.2 & 7 & 98.78 \\
\hline Communication & 496.8 & 2 & 9.936 \\
\hline Transportation costs & 2073.6 & 6 & 124.42 \\
\hline Healthcare, education & 3982 & 1 & 39.82 \\
\hline Leisure and sports & 5637.6 & 4 & 225.50 \\
\hline Others & 7458.8 & 5 & 372.94 \\
\hline Total & 36000 & & 1319.6 \\
\hline
\end{tabular}

Thus, for the year, the budget will indirectly receive 1319.6 USD in the form of tax deductions. If we accept the expert assessment that more than 100 thousand Russian 
seafarers work for foreign ship owners, then the annual budget receipts from their consumer expenditures will amount to at least 131,960,000 USD.

\section{Discussion}

Expansion of labor migration of seafarers is an objectively developing process caused by many reasons, including: a small share of Russian sea-going ships, which transport no more than $4 \%$ of the national cargo base; higher wages at foreign ship owners; significant demand for Russian seafarers in the international crewing market, where the level of their professional training is recognized as very high.

A natural question arises - is it profitable for the state to export such qualified labor resources? Without going deep into the political, social, moral aspects of this problem, let us dwell on the financial and economic component. When exporting labor,reimbursement to the state is carried out in two main directions:

- directly - tax revenues to the budget from legal entities - intermediaries organizing the selection, direction, and sometimes training of personnel for work abroad;

- indirectly - from individuals in the form of money earned outside and imported (listed), spent in Russia. This increases consumer demand, activating entrepreneurial activity in the state.

The enlarged calculations performed showed that for the year, the state budget will receive at least 131.9 million USD indirectly from the consumer expenses of 100 thousand seafarers working for foreign ship owners in the form of tax deductions. Perhaps, this figure is not so significantfor the Russian budget.However, this is an additional contribution to the gross domestic product of the state from only one category of workers who work abroad.

If these seafarers would work on Russian ships, then with the analyzed annual salary of one employee at USD 36,000, the personal income tax would be USD 4680 per year, and with 100 thousand people - USD 468 million. At the same time, they would also spend the money they earned in Russia, activating the national business. Of course, from the state standpoint, this option is more attractive, but the current situation on the seafarers' labor market requires an economic assessment and taking measures to regulate it.

\section{Conclusions}

The tax aspects of foreign income of seafarers require deeper scientific research and organizational measures to create:

- comparable terms of payment for their labor on Russian and foreign ships;

- attractive conditions for seafarers to pay tax and insurance premiums in the form of self-employed citizens;

- a unified procedure for the payment of certain contributions to the off-budget funds of the Russian Federation.

Considering that migratory labor processes are characterized by many controversial issues that can be interpreted both positively and negatively, it must be admitted that this form of employment for seafarers will develop. Therefore, the current global trends require state regulation in the organizational, economic, and most importantly, tax aspects, which, with effective management, will help to increase the revenue side of the budget and ensure social protection of this category of Russian citizens.

\section{References}

1. Kyriaki Mitroussi, Marine Policy 32(6), 1043-1049 (2008) 
2. Kum Fai Yuen, Hui Shan Loh, Qingji Zhou, Yiik Diew Wong, Transportation Research Part A: Policy and Practice, Elsevier 110(C), 1-12 (2018)

3. Merika Anna Triantafyllou, Anna Zombanakis George, Transportation Research Part A: Policy and Practice 119, 255-2704 (2019)

4. Ying Wanga, Gi Tae Yeob, The Asian Journal of Shipping and Logistics 32(4), 221227 (2016)

5. V.V. Thai, L. Balasubramanyam, K. Kai Lin Yeoh, S. Norsofiana, Maritime Policy \& Management, Taylor \& Francis Journals 40(1), 80-94 (2013)

6. L. Kluchnyk, S. Davymuka, Economic and Regional Studies (Studia Ekonomicznei Regionalne), Pope John Paul II State School of Higher Education in Biala Podlaska 13(3) (2020)

7. H.S. Farber, Handbook of Labor Economics 3(B), 2439-2483 (1999)

8. Y. Solomka, University Economic Bulletin, Pereiaslav-Khmelnytskyi Hryhorii Skovoroda State Pedagogical University, Faculty of Finance and Humanities 46, 153160, September 2020

9. H. Toch, Income Tax. 1st Edition (Made Simple, 1985)

10. G.N. Gregoriou, C. Read, International Taxation Handbook. 1st Edition. Policy, Practice, Standards, and Regulation (CIMA Publishing, 2007)

11. E. Lavrenteva, Advances in Intelligent Systems and Computing 983, 146-157 (2019) 